\title{
Analisis Pola Spasial Penyakit Demam Berdarah Dengue di Kota Bandung Menggunakan Indeks Moran
}

\author{
Rika Hernawati, Muhamad Yordi Ardiansyah \\ Jurusan Teknik Geodesi, Institut Teknologi Nasional (Itenas) Bandung \\ Email: rikah@itenas.ac.id
}

\begin{abstract}
Bandung has the highest case of dengue fever in West Java, which is 3134 cases in 2014. The spread of dengue fever can be analyzed spatially by spatial autocorrelation to find out the correlation relationship pattern between locations. The method of spatial autocorrelation was using the Moran Index method. From these methods can determine the relationship of spatial autocorrelation in the spread of dengue fever and determine spatial distribution pattern of dengue fever in Bandung. The results of spatial autocorrelation analysis shows the spatial autocorrelation in dengue hemorrhagic cases in Bandung, the one-way significance test indicates a positive autocorrelation in Dengue hemorrhagic cases in Bandung and spatial distribution pattern is the spatial distribution pattern of the cluster.
\end{abstract}

Kata kunci: spatial autocorrelation, spatial pattern, Moran Index, dengue fever.

\begin{abstract}
ABSTRAK
Kota Bandung merupakan kota yang mempunyai kasus penyakit demam berdarah tertinggi di Jawa Barat yang berjumlah 3134 kasus pada tahun 2014. Sebaran penyakit demam berdarah dapat dianalisis secara spasial yaitu dengan autokorelasi spasial untuk mengetahui pola hubungan korelasi antar lokasi. Metode autokorelasi spasial yang digunakan adalah metode Indeks Moran. Dari metode tersebut dapat menentukan hubungan autokorelasi spasial dalam penyebaran penyakit demam berdarah dan menentukan pola sebaran spasial penyakit demam berdarah di Kota Bandung. Dari hasil analisis autokorelasi spasial menunjukan terdapat autokorelasi spasial pada kasus demam berdarah dengue di Kota Bandung, uji signifikansi satu arah menunjukan adanya autokorelasi positif pada kasus demam berdarah Dengue di Kota Bandung dan pola sebaran spasial dihasilkan adalah pola spasial sebaran cluster.
\end{abstract}

Keywords: Autokorelasi Spasial, Pola Spasial, Indeks Moran, demam berdarah. 


\section{PENDAHULUAN}

Menurut catatan Dinas Kesehatan Kota Bandung, pada tahun 2014 terdapat 3134 kasus demam berdarah yang terjadi di Kota Bandung. Penyebab melonjaknya kasus DBD selain cuaca, perilaku hidup bersih dan sehat (PHBS) belum sepenuhnya diterapkan masyarakat [1]. DBD identik dengan hujan, akan tetapi pada saat musim kemarau kasus DBD tetap banyak, hal ini ditunjang mobilitas penduduk semakin tinggi, jadi faktor pencetus DBD di Kota Bandung banyak, ditambah PHBS masih lemah [1]. Demam Berdarah Dengue disebabkan oleh virus dengue yang ditularkan melalui gigitan nyamuk Aedes aegypti dan Aedes albopictus yang sebelumnya telah terinfeksi oleh virus dengue dari penderita demam berdarah lainnya. Kedua jenis nyamuk Aedes ini terdapat hampir di seluruh pelosok Indonesia, nyamuk Aedes umumnya menyukai tempat di air bersih yang tidak berhubungan langsung dengan tanah meletakan telur pada permukaan air bersih secara individual. Melihat tingginya jumlah kasus Demam Berdarah Dengue di Kota Bandung, maka perlu dilakukan penelitian untuk mengetahui pola sebaran spasial yang berhubungan dengan penyakit tersebut salah satunya dengan menggunakan pendekatan statistika spasial. Analisis spasial digunakan untuk mendeteksi dan mengukur pola kejadian penyakit yang dapat memberikan wawasan epidemiologi penyakit [2]. Oleh karena itu, diperlukan suatu analisis data spasial dengan menggunakan metode autokorelasi spasial untuk mengetahui pola hubungan atau korelasi antar lokasi. Autokorelasi spasial adalah korelasi antara variabel dengan dirinya sendiri berdasarkan ruang atau dapat juga diartikan suatu ukuran kemiripan dari objek didalam suatu ruang (jarak, waktu, dan wilayah) [3]. Adanya autokorelasi spasial mengindikasikan bahwa nilai atribut pada daerah tertentu terkait oleh nilai atribut tersebut pada daerah lain yang letaknya berdekatan (bertetangga). Analisis spasial penyakit demam berdarah untuk mengetahui autokorelasi spasial salah satu metode yang digunakan adalah metode Indeks Moran. Menurut Rosli dkk. [2] indeks Moran merupakan teknik dalam analisis spasial untuk menghitung hubungan spasial yang terjadi dalam ruang unit.

Penelitian analisis spasial mengenai penyakit demam berdarah sudah banyak dilakukan, misalnya penelitian yang dilakukan oleh Kanchana Nakhapakorn dan Supet Jirakajohnkool pada tahun 2006 di Sukhothai, Thailand [4] dan Rheni Puspitasari dan Irwan Susanto pada tahun 2011 di Sukoharjo, Jawa Tengah [5], yaitu mengenai analisis kasus demam berdarah menggunakan Indeks Moran. Penelitian sejenis untuk wilayah Kota Bandung dan sekitarnya belum banyak dilakukan. Dalam penelitian ini hubungan spasial diperlukan untuk mengetahui apakah terdapat autokorelasi spasial dalam penyebaran penyakit demam berdarah yang terjadi di Kota Bandung dan dapat mengetahui pola sebaran penyakit demam berdarah di Kota Bandung, dari hasil tersebut dapat digunakan sebagai referensi atau acuan oleh dinas kesehatan untuk mengantisipasi penyakit demam berdarah. Data yang digunakan berupa data jumlah kasus penyakit demam berdarah pada tahun 2014 di Kota Bandung dan data spasial yaitu peta administrasi Kota Bandung. 


\subsection{Data}

\section{METODOLOGI PENELITIAN}

Data yang digunakan adalah:

a. Data kasus demam berdarah per kecamatan (30 kecamatan) di Kota Bandung tahun 2014 yang bersumber dari Dinas Kesehatan Kota Bandung.

Tabel 1. Data Jumlah Kasus Demam Berdarah Dengue di Kota Bandung Tahun 2014 (Sumber: Dinas Kesehatan Kota Bandung, 2014)

\begin{tabular}{|c|l|c|c|c|c|}
\hline \multicolumn{7}{|c|}{ DATA JUMLAH KASUS DEMAM BERDARAH DENGUE } \\
\hline No & \multicolumn{1}{|c|}{ KECAMATAN } & JUMLAH KASUS & No & KECAMATAN & JUMLAH KASUS \\
\hline \hline 1 & BANDUNG KULON & 75 & 16 & ARCAMANIK & 105 \\
\hline 2 & BABAKAN CIPARAY & 155 & 17 & ANT APANI & 148 \\
\hline 3 & BOJONGLOA KALER & 106 & 18 & MANDALAJATI & 61 \\
\hline 4 & BOJONGLOA KIDUL & 100 & 19 & KIARACONDONG & 172 \\
\hline 5 & AST ANAANYAR & 96 & 20 & BATUNUNGGAL & 165 \\
\hline 6 & REGOL & 143 & 21 & SUMUR BANDUNG & 80 \\
\hline 7 & LENGKONG & 236 & 22 & ANDIR & 72 \\
\hline 8 & BANDUNG KIDUL & 108 & 23 & CICENDO & 64 \\
\hline 9 & BUAHBATU & 202 & 24 & BANDUNG WETAN & 39 \\
\hline 10 & RANCASARI & 135 & 25 & CIBEUNYING KIDUL & 124 \\
\hline 11 & GEDEBAGE & 52 & 26 & CIBEUNYING KALER & 72 \\
\hline 12 & CIBIRU & 76 & 27 & COBLONG & 134 \\
\hline 13 & PANYILEUKAN & 44 & 28 & SUKAJADI & 86 \\
\hline 14 & UJUNG BERUNG & 107 & 29 & SUKASARI & 111 \\
\hline 15 & CINAMBO & 28 & 30 & CIDADAP & 38 \\
\hline
\end{tabular}

b. Peta batas administrasi Kota Bandung skala 1:50.000, yang bersumber dari Pusdalisbang (Pusat Data dan Analisa Pembangunan) Provinsi Jawa Barat. 


\subsection{Metode}

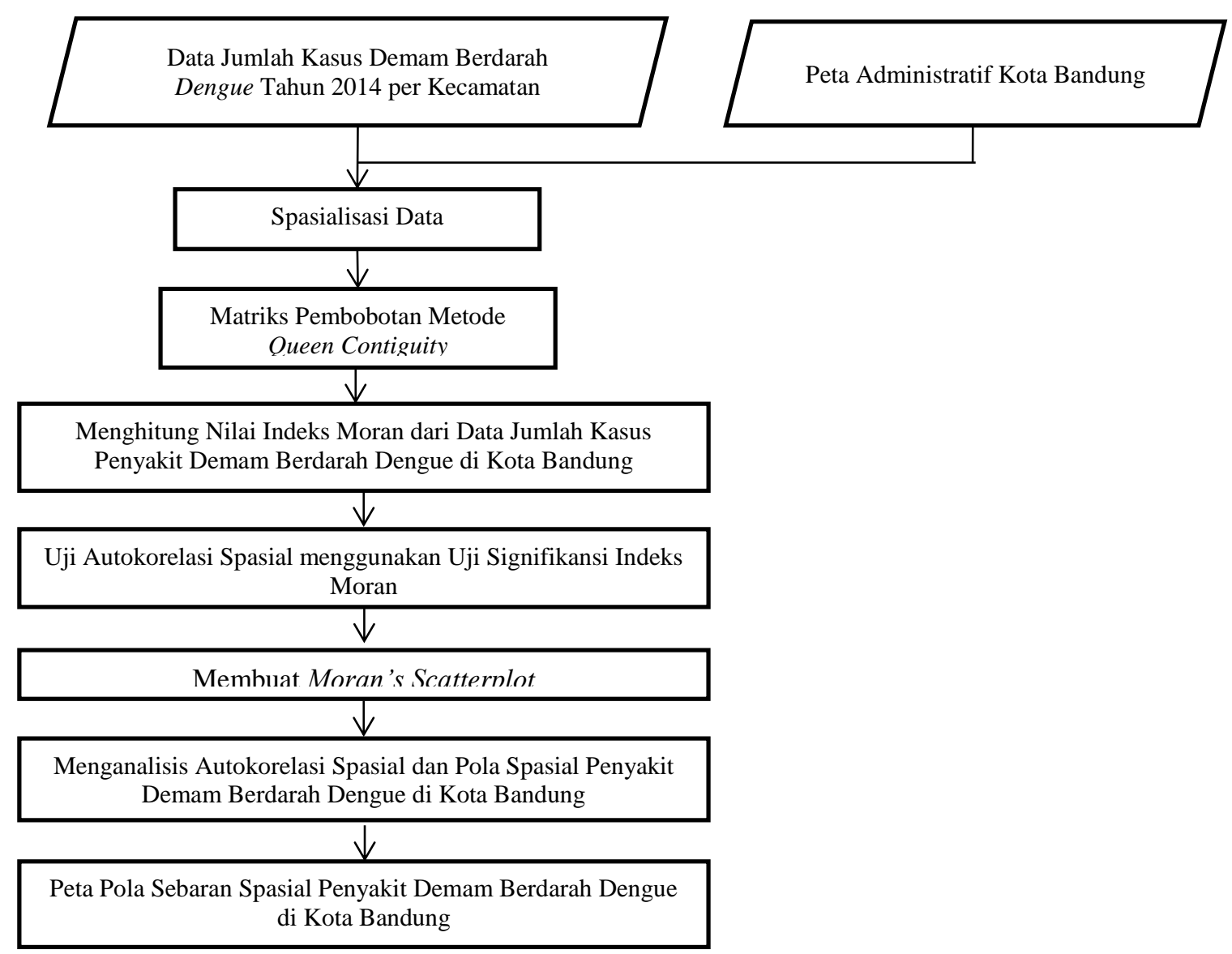

Gambar 1. Metodologi Penelitian

Pengumpulan data-data yang diperlukan, yaitu data kasus penyakit demam berdarah tiap Kecamatan di Kota Bandung pada Tahun 2014 dan peta administrasi Kota Bandung. Kemudian melakukan proses penggabungan data peta batas administrasi wilayah Kota Bandung dengan data jumlah kasus Demam Berdarah Dengue. Proses penggabungan bertujuan untuk merepresentasikan data kualitatif dan kuantitatif secara visual. Sehingga dapat diperoleh data spasial penyakit Demam Berdarah Dengue. data spasial tersebut memberikan informasi yang sudah terintegras, yaitu lokasi administrasi wilayah dalam bentuk vektor dan informasi atribut berupa jumlah kasus Demam Berdarah Dengue di setiap lokasi. Selanjutnya dilakukan proses perhitungan menggunakan metode statistika spasial untuk mengetahui apakah data tersebut saling memiliki korelasi.

Tahap berikutnya yaitu membuat matriks pembobotan. Dalam analisis spasial untuk mengetahui adanya autokorelasi komponen utama yang diperlukan adalah peta lokasi. Peta digunakan untuk menentukan hubungan kedekatan Kecataman Kota Bandung, dengan demikian akan lebih mudah untuk memberikan pembobotan pada masing-masing lokasi atau kecamatan. Dari peta Kota Bandung diketahui bahwa terdapat 30 Kecamatan sehingga matriks pembobotan akan berukuran 30 x 30 . Metode matriks pembobotan matriks yang digunakan adalah Queen Cotiguity dan cara memperoleh matriks pembobotan spasial berdasarkan standardize contiquity matrix $\mathbf{W}$ (matriks pembobotan standarisasi) diperoleh dengan cara memberi nilai atau bobot yang sama rata terhadap tetangga lokasi terdekat dan lokasi yang lainnya diberi bobot nol [6]. 
Daerah pengamatannya ditentukan berdasarkan sisi-sisi yang saling bersinggungan dan sudut juga diperhitungkan. Ilustrasi untuk queen contiguity dapat dilihat pada Gambar 2, dimana B1, B2, B3, dan B4 serta C1, C2, C3, dan C4 merupakan tetangga dari A.

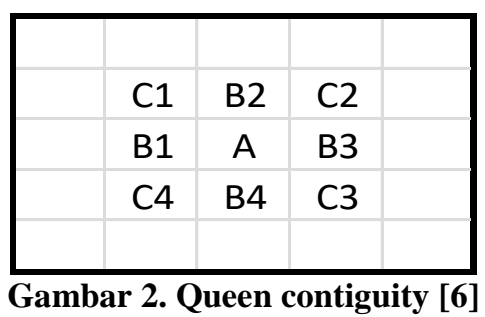

Berdasarkan matriks pembobotan spasial, dapat diketahui jumlah tetangga lokasi yang dimiliki oleh masing-masing Kecamatan.

Menghitung nilai Indeks Moran. Metode Indeks Moran merupakan metode yang sering digunakan untuk pengukuran autokorelasi spasial global. Indeks Moran dapat diaplikasikan untuk mendeteksi feature spasial acak yang mengindikasikan bentuk pola spasial yang berkelompok (cluster), menyebar ataupun acak seperti pada Gambar 3. Indeks Moran menghitung perbedaan antara nilai sebuah feature dan nilai rata-rata untuk semua feature dan perbedaan antara nilai feature pada masing-masing tetangga terhadap nilai rata-rata [7].

Perhitungan dilakukan dengan menggunakan rumus sebagai berikut [7]:

$I=\frac{N}{\sum i \sum j w i j} \frac{\sum i \sum j w i j(X i-\bar{X})(X i-\bar{X})}{\sum i(X i-\bar{X})^{2}}$

Dimana :

I = nilai Moran's I

$\mathrm{N} \quad=$ banyaknya lokasi kejadian

$\mathrm{Xi} \quad=$ nilai pada lokasi $\mathrm{i}$

$\mathrm{Xj} \quad=$ nilai pada lokasi $\mathrm{j}$

$\bar{X} \quad=$ rata-rata jumlah variabel

Wij = elemen pada pembobotan antara daerah $\mathrm{i}$ dan $\mathrm{j}$

Nilai Moran I (I) yang diperoleh dari hasil perhitungan autokorelasi spasial dapat mengindikasi pola feature yang terbentuk. Adapun pola feature yang terbentuk berdasarkan nilai Moran's I dapat dilihat pada Tabel 2.

Tabel 2 Pola Feature yang Terbentuk

\begin{tabular}{|c|l|}
\hline Moran's I & \multicolumn{1}{|c|}{ Keterangan } \\
\hline \hline $\mathrm{I}>0$ & Kluster ( terdapat banyak kemiripan niali pada feature ) \\
\hline $\mathrm{I}<0$ & Acak ( pola feature tidak jelas ) \\
\hline $\mathrm{I}=0$ & Menyebar ( nilai feature yang tinggi dan rendah menyebar dalam dataset \\
\hline
\end{tabular}

Sumber: (Mitchell, 2005)

Selain dapat mengetahui pola feature yang terbentuk nilai Indeks Moran hasil perhitungan juga dipergunakan untuk menghitung autokorelasi spasial. Ada atau tidaknya autokorelasi spasial dalam 
sebuah dataset dilakukan uji statistik Moran's I dengan nilai harapannya. Adapun tahapan uji statistic sebagai berikut ( Lee dkk, 2001 ):

1. Penentuan hipotesis nol (H0) dan hipotesis alternative, hipotesis uji satu arah autokorelasi spasial yaitu :

$\mathrm{H}_{0}: \mathrm{I}=0$, tidak ada autokorelasi spasial. Untuk hipotesis alternatifnya adalah:

$\mathrm{H}_{1}: \mathrm{I}>0$, artinya terdapat autokorelasi spasial positif

$\mathrm{H}_{1}: \mathrm{I}<0$, artinya terdapat autokorelasi spasial negatif

H0 ditolak jika nilai $|Z(I)|>Z(\alpha)$ atau $|Z(I)|<-Z(\alpha)$ sehingga terdapat autokorelasi spasial.

2. Penentuan nilai kritis, nilai $Z$ kritis $(Z(\alpha))$ dihitung dengan $\alpha / 2$ untuk derajat kepercayaan $99 \%$.

3. Penentuan nilai uji, nilai uji $(Z(I))$ dihitung dengan tahapan sebagai berikut :

a. Menghitung nilai harapan statistik (E(I)) menggunakan rumus :

$$
E(I)=\frac{1}{(n-1)}
$$

b. Menghitung nilai variansi menggunakan rumus :

$$
\operatorname{VAR}(I)=\frac{n^{2} S^{1}-n S^{2}+3(C)^{2}}{(C)^{2}\left(n^{2}-1\right)}
$$

Dimana :

$$
\begin{aligned}
& C=\sum_{i=1}^{n} C \sum_{j=1}^{n} C i j \\
& \boldsymbol{S 1}=\frac{\sum_{i=1}^{n} C \sum_{j=\mathbf{1}}^{n}(C i j+C j i)^{2}}{2}
\end{aligned}
$$

Dimana :

$\mathrm{Cij}=$ elemen matriks contiguity

$\mathrm{Ci}=$ total nilai baris ke-I matriks contiguity

$\mathrm{Cj} \quad=$ total niali kolom ke-I matriks contiguity

c. Menghitung nilai uji statistik menggunakan rumus :

$$
\begin{aligned}
& Z(I)=\frac{I-E(I)}{\sqrt{V A R(I)}} \\
& \text { Dimana : } \\
& \text { I } \quad=\text { nilai Moran's I } \\
& Z(I) \quad=\text { nilai statistik uji Moran's I } \\
& \text { E(I) = nilai harapan dari Moran's I } \\
& \text { VAR(I })=\text { variansi dari Moran's I }
\end{aligned}
$$

4. Pengambilan keputusan, keputusan yang diambil mengacu kepada diterima atau tidak hipotesis nol dan hipotesis altrnatif, adapun keputusan yang dapat diambil yaitu :
a. Menerima H0, bila nilai uji berada dibawah nilai kritis atas,
b. Menerima $\mathrm{HO}$, bilai nilaiuji diatas nilai kritis bawah
c. Menolak H0, jika nilai uji dibawah nilai kritis bawah
d. Menolak H0, jika nilai uji di atas nilai kritis atas
e.

Selanjutnya mengidentifikasi autokorelasi yang terjadi apakah termasuk autokorelasi positif atau autokorelasi negatif. Untuk pola pengelompokan dan penyebaran antar lokasi dapat disajikan dengan Moran's Scatterplot yang menunjukkan hubungan antara nilai amatan pada suatu lokasi (distandarisasi) dengan rata-rata nilai amatan dari lokasi-lokasi yang bertetanggaan dengan lokasi yang bersangkutan.

Moran's Scetterplot adalah salah satu cara untuk menginterpretasikan statistik Moran's I. Moran's Scetterplot merupakan alat untuk melihat hubungan antara Zstd (nilai pengamatan yang distandarisasi) 
dengan nilai rata-rata lokal yang dihitung dari matriks pembobot WZstd (nilai rata-rata lokal yang dihitung dari matriks pembobot spasial). Untuk lebih jelas dapat dilihat pada Gambar 3.

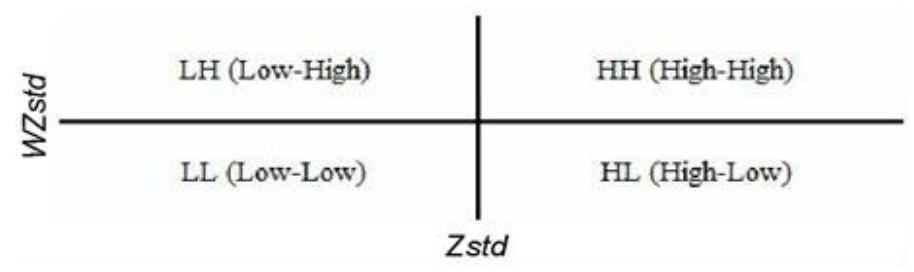

Gambar 3. Ilustrasi nilai Zstd dan WZstd pada Morans Scatterplot [8]

Moran's Scatterplot terbagi atas 4 kuadran. Kuadran I (terletak di kanan atas) disebut High-High $(\mathrm{HH})$, menunjukan daerah yang mempunyai nilai pengamatan tingg dikelilingi oleh daerah yang mempunyai nilai pengamatan tinggi. Kuadran II (terletak di kiri atas) disebut Low-High (LH), menunjukan daerah dengan pengamatan rendah tapi dikelilingi oleh daerah dengan nilai pengamatan tinggi. Kuadran III (terletak di kiri bawah) disebut Low-Low (LL), menunjukan daerah dengan nilai pengamatan rendah dan dikelilingi oleh daerah dengan nilai pengamatan rendah. Kuadran IV (terletak di kanan bawah) disebut High-Low (HL), menunjukan daerah dengan nilai pengamatan tinggi yang dikelilingi oleh daerah dengan nilai pengamatan rendah [8].

Moran's Scetterplot yang banyak menempatkan pengamatan di kuadran HH dan kuadran LL akan cenderung mempunyai nilai autokorelasi spasial yang positif. Sedangkan Moran's Scatterplot yang banyak menempatkan pengamatan di kuadran HL dan LH akan cenderung mempunyai nilai atokorelasi spasial yang negatif. Untuk memperjelas hasil analisis, maka posisi masing-masing pengamatan pada Moran's Sceterrplot dapat dipetakan pada masing-masing letak geografis daerah dalam suatu peta tematik.

Dari proses pengolahan data tersebut menggunakan metode Moran's I di dapat hasil berupa Scetterplot dan Peta pola sebaran penyakit Demam Berdarah Dengue di Kota Bandung.

\subsection{Wilayah Studi}

Pada penelitian ini yang dijadikan wilayah studi adalah daerah Kota Bandung yang terletak di Provinsi Jawa Barat tepatnya $\left(6^{\circ} 54^{\prime} 53,08^{\prime \prime}\right)$ LU dan $\left(107^{\circ} 36^{\prime} 35,32^{\prime \prime}\right)$ BT, serta berada pada ketinggian $\pm 768 \mathrm{~m}$ di atas permukaan laut, dengan titik tertinggi di berada di sebelah utara dengan ketinggian 1.050 meter di atas permukaan laut dan sebelah selatan merupakan kawasan rendah dengan ketinggian 675 meter di atas permukaan laut. Secara administratif Kota Bandung dibagi menjadi 30 kecamatan. 


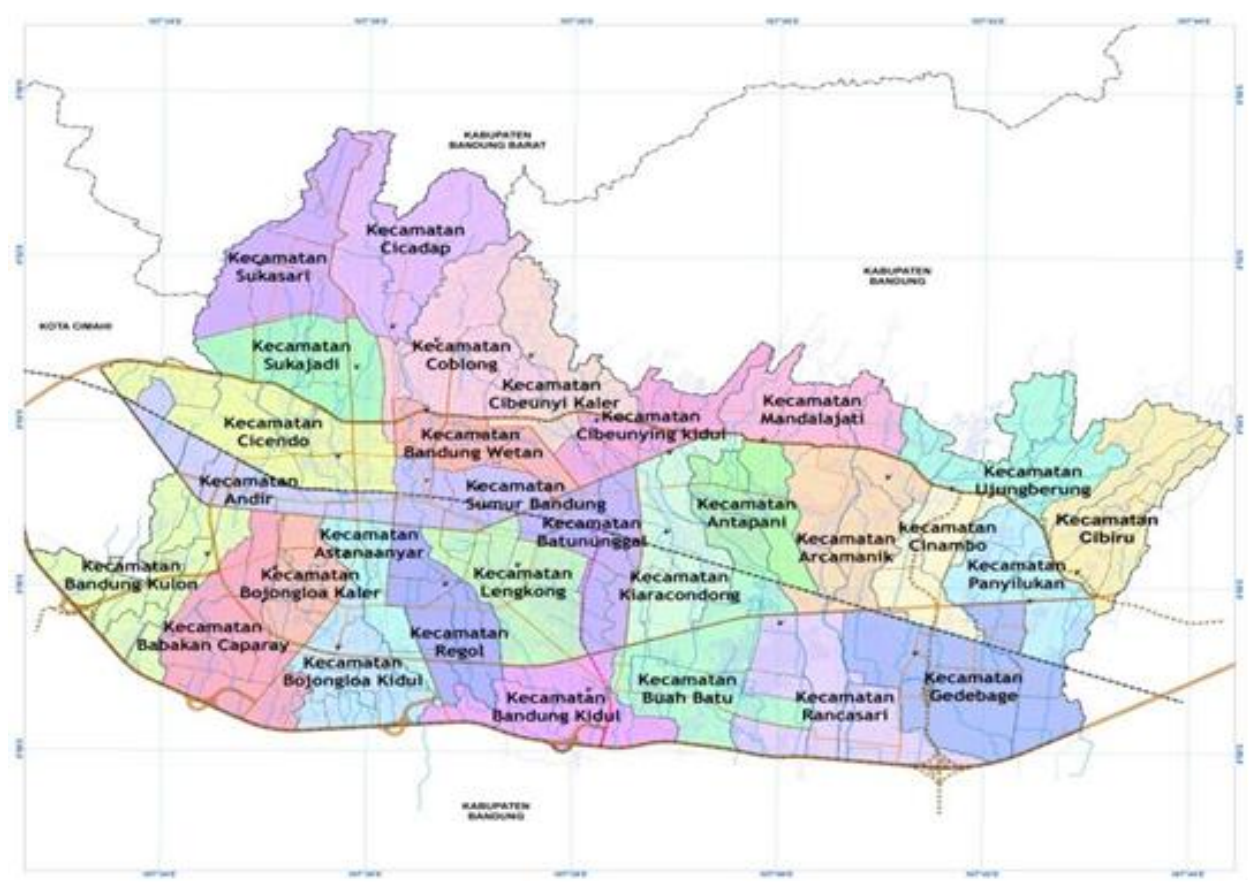

Gambar 4. Peta Administratrif Kota Bandung

\section{HASIL DAN PEMBAHASAN}

\subsection{Hasil Perhitungan Autokorelasi Spasial}

Hasil yang diperoleh dari penelitian ini adalah berupa informasi mengenai kecamatan-kecamatan yang berada di Kota Bandung yang memiliki data kasus demam berdarah Dengue saling berkolerasi antara kecamatan yang satu dengan kecamatan yang lain. Proses autokorelasi spasial digunakan untuk mengetahui pola penyebaran penyakit demam berdarah Dengue yang terjadi di seluruh kecamatan di Kota Bandung. Dari data penyakit demam berdarah Dengue tersebut membentuk pola-pola mengelompok pada lokasi tertentu.

Hasil perhitungan autokorelasi spasial pada penyakit demam berdarah Dengue dapat dilihat pada Tabel 3.

Tabel 3. Hasil Proses Autokorelasi Spasial (Indeks Moran) Penyakit Demam Berdarah Dengue

\begin{tabular}{|c|c|c|c|c|}
\hline Moran's I & Nilai Harapan & Variansi & $Z$-score & $P$-value \\
\hline 0,227025 & 2,311392 & 0,0128 & 2,311392 & 0,020811 \\
\hline
\end{tabular}

Dari hasil perhitungan autokorelasi spasial dengan menggunakan metode Indeks Moran, maka dapat diketahui parameter-parameter meliputi nilai Indeks Moran sebesar 0,227025 nilai tersebut kurang dari 2,58 hipotesis H0 ditolak sehingga terdapat autokorelasi spasial pada penyakit demam berdarah Dengue, nilai harapan (Expected Value) sebesar -0,034483 ,nilai variansi -0,034483, nilai z-score 2.311392, dan p-value 0,020811. Parameter-parameter tersebut selanjutnya digunakan untuk perhitungan uji statistik, sehingga dapat diketahui ada atau tidak ada autokorelasi spasial pada data jumlah kasus Demam Berdarah Dengue dan bagaimana pola sebaran yang terbentuk.

Adapun hasil uji statistik penyakit demam berdarah Dengue dapat dilihat pada Tabel 4. 
Tabel 4. Uji Signifikansi Moran's I pada Penyakit Demam Berdarah Dengue

\begin{tabular}{|c|c|c|c|c|}
\hline Moran's I & $\mathbf{Z ( I )}$ & $\mathbf{Z ( a / 2 )}$ & Uji Statistik & Keterangan \\
\hline \multirow{2}{*}{0,227025} & 2,311392 & 2,58 & $\begin{array}{c}2,311392<2,58 \text { maka } \mathrm{HO} \\
\text { ditolak }\end{array}$ & $\begin{array}{c}\text { Autokorelasi } \\
\text { positif, pola } \\
\text { spasial } \\
\text { membentuk } \\
\text { Cluster }\end{array}$ \\
& & $\begin{array}{c}0,227025>0 \text { maka } \mathrm{H} 1 \\
\text { diterima }\end{array}$ & \begin{tabular}{c} 
master \\
\hline
\end{tabular}
\end{tabular}

Hasil uji statistik memberikan informasi bahwa terdapat hubugan spasial pada kasus penyakit demam berdarah Dengue dimana hasil perhitungan H0 ditolak dan H1 diterima sehingga memiliki autokorelasi spasial positif dan pola sebaran yang terbentuk merupakan pola Cluster.

Adapun hasil analisis autokorelasi spasial penyakit demam berdarah Dengue dapat dilihat pada Gambar 5 .

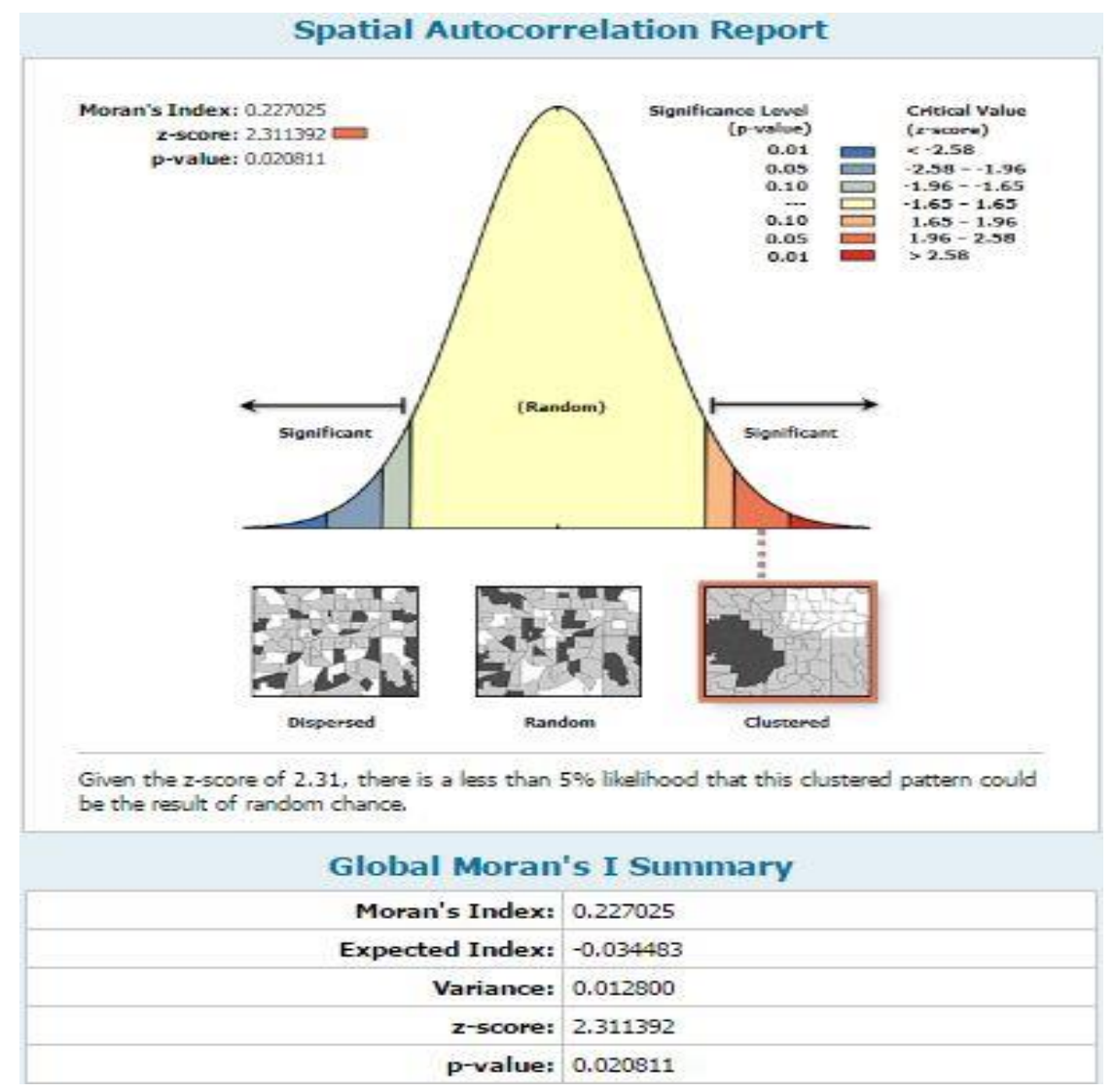

Gambar 5. Hasil Analisis Autokorelasi Spasial Penyakit Demam Berdarah Dengue

Dari hasil analisis autokorelasi spasial penyakit Demam Berdarah Dengue pada Gambar 5 diperoleh nilai indeks Moran sebesar 0,227025, nilai harapan sebesar -0,034483, variansi 0,012800. Hasil analisis autokorelasi spasial ini mengevaluasi apakah pola dinyatakan mengelompok, menyebar, atau acak.

Ketika z-score atau p-value menunjukkan signifikansi statistik, nilai indeks Moran positif mengindikasikan kecenderungan pengelompokan sedangkan nilai indeks Moran negatif mengindikasikan kecenderungan menyebar. z-score dan p-value adalah ukuran signifikansi statistik yang memberitahu ada atau tidak untuk menolak hipotesis nol. Hipotesis nol menyatakan bahwa nilainilai yang terkait dengan kasus demam berdarah Dengue didistribusikan secara acak. Mengingat z- 
score 2.311392, ada kurang dari 5\% kemungkinan bahwa pola berkerumun ini bisa menjadi hasil dari kebetulan acak, sehingga mempunyai nilai kepercayaan sebesar $95 \%$.

\subsection{Pembahasan}

a) Data

Data yang digunakan pada penelitian ini adalah data penyakit Demam Berdarah Dengue tahun 2014, data tersebut diperoleh dari Dinas Kesehatan Kota Bandung. Data tersebut berisi jumlah kasus penyakit demam berdarah ditiap Kecamatan dengan jumlah 30 Kecamatan di Kota Bandung. Data-data tersebut dianalisis secara spasial untuk mengetahui ada atau tidak autokorelasi spasial yang terjadi di setiap kecamatan dan bagaimana bentuk pola sebaran spasial yang terjadi dari hasil proses autokorelasi spasial.

b) Moran's Scatterplot

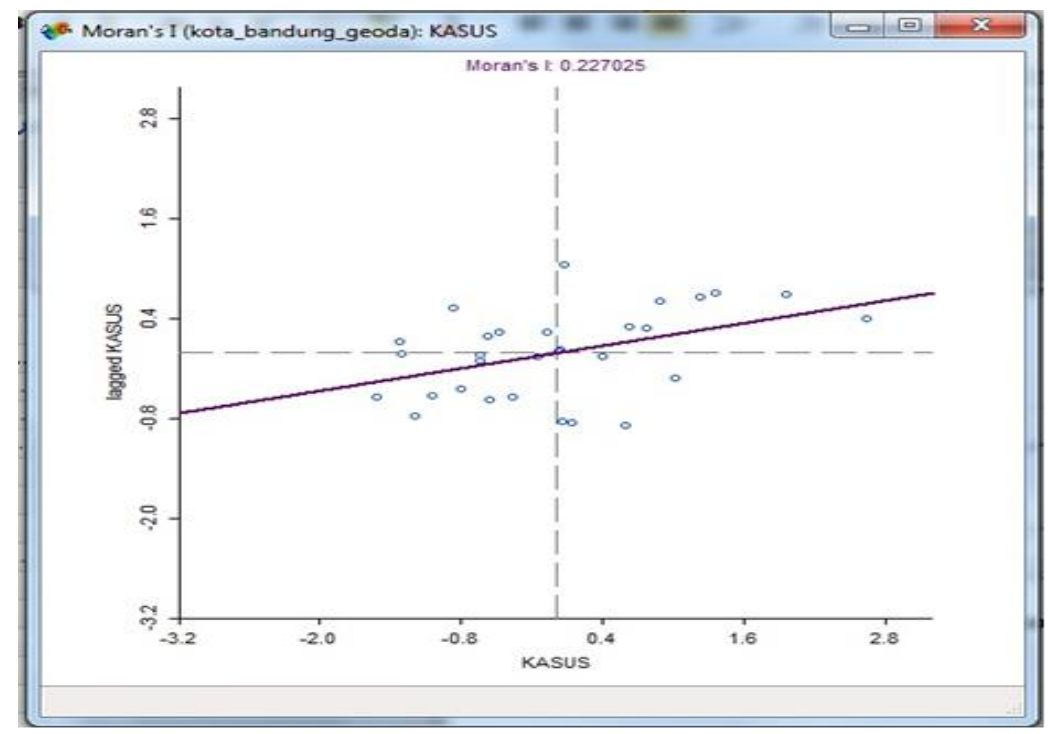

Gambar 6. Moran's Scatterplot Penyakit Demam Berdarah Dengue

Analisis Moran's Scatterplot penyakit demam bardarah Dengue diperoleh hasil sebaran nilainilai pengamatan sebagai berikut:

Kuadran I: Arcamanik, Rancasari, Buah Batu, Antapani, Kiaracondong, Bandung Kidul, Batununggal, Lengkong, Regol, Bojongloa Kaler. Kecamatan ini memiliki nilai penyakit demam berdarah tinggi dan dikelilingi oleh kecamatan lain yang memiliki nilai penyakit demam berdarah tinggi pula (High-High).

Kuadran II: Mandalajati, Sumur Bandung, Cibeunying Kaler, Cidadap, Sukasari, Bojongloa Kidul, Bandung Kulon. Kecamatan ini memiliki nilai penyakit demam berdarah rendah dan dikelilingi oleh kecamatan lain yang memiliki nilai penyakit demam berdarah tinggi (LowHigh).

Kuadran III: Cibiru, Panyileukan, Gedebage, Cinambo, Sukajadi, Cicendo, Andir, Astanaanyar. Kecamatan ini memiliki nilai penyakit demam berdarah rendah dan dikelilingi oleh kecamatan lain yang memiliki nilai penyakit demam berdarah rendah pula (Low-Low).

Kudran IV: Ujung Berung, Cibeunying Kidul, Bandung Wetan, Coblong, Babakan Ciparay. Kecamatan ini memiliki nilai penyakit demam berdarah tinggi dan dikelilingi oleh kecamatan lain yang memiliki nilai penyakit demam berdarah rendah (High-Low). 


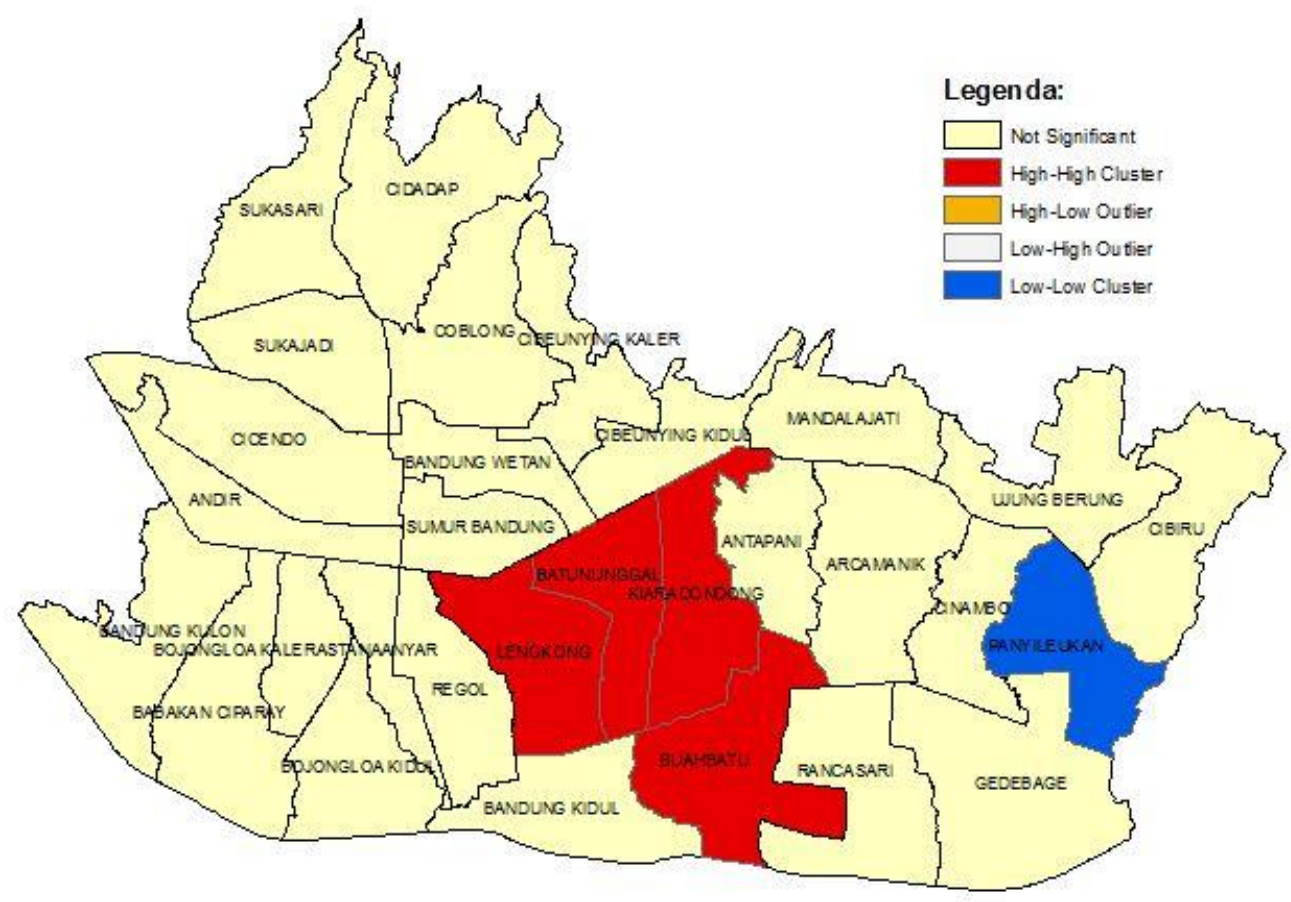

\section{Gambar 7. Visualisasi Autokorelasi Spasial Penyakit Demam Berdarah Dengue}

Dari Gambar 7. diketahui pola spasial penyakit Demam Berdarah Dengue yang termasuk pola Cluster berada pada kuadran I (High-High), kuadran III (Low-Low). Kecamatan-kecamatan yang termasuk ke dalam pola Cluster kuadran I (High-High) antara lain: Kecamatan Batununggal (165 Kasus DBD), Buahbatu (202 Kasus DBD), Kiaracondong (172 Kasus DBD), Lengkong ( 236 Kasus DBD). Sedangkan untuk kecamatan-kecamatan yang termasuk ke dalam pola Cluster kuadran III (Low-Low) adalah Kecamatan Panyileukan (44 Kasus DBD).

\section{KESIMPULAN}

Dari hasil analisis autokorelasi spasial penyakit Demam Berdarah Dengue yang terjadi di Kota Bandung, dapat disimpulkan bahwa terdapat autokorelasi spasial yaitu autokorelasi spasial yang bersifat positif. Dari hasil uji signifikansi metode indeks Moran dapat disimpulkan bahwa pola sebaran spasial yang terbentuk penyakit Demam Berdarah Dengue di Kota Bandung memiliki pola sebaran mengelompok (Cluster). Adapun peta pola sebaran spasial penyakit demam bardarah Dengue yang terjadi di Kota Bandung dapat disimpulkan bahwa pada peta pola sebaran spasial penyakit Demam Berdarah Dengue, kecamatan-kecamatan yang termasuk pola Cluster (kuadran I (High-High) dan kuadran III (Low-Low)) antara lain: Kecamatan Batununggal, Buahbatu, Kiaracondong, Lengkong (High-High) dan Kecamatan Panyileukan (Low-Low).

\section{DAFTAR PUSTAKA}

[1] Pikiran Rakyat. (2016). Kasus Demam Berdarah Terbanyak Terjadi di Kota Bandung. Pikiran Rakyat Online. http://www.pikiran-rakyat.com/bandung-raya/2016/11/04/kasus-demamberdarah-terbanyak-terjadi-di-kota-bandung-waspadalah-383883.

[2] Rosli, dkk (2010). Spatial mapping of dengue incidence: A case study in Hulu Langat District, Selangor, Malaysia. International Journal of Human and Social Sciences, 5(6), 410-414. 
[3] Gardner, B., Sullivan, P. J., Lembo, Jr, A. J. (2003). Predicting stream temperatures: geostatistical model comparison using alternative distance metrics. Canadian Journal of Fisheries and Aquatic Sciences, 60(3), 344-351.

[4] Nakhapakorn, K., \& Jirakajohnkool, S. (2006). Temporal and spatial autocorrelation statistics of dengue fever. Dengue Bulletin-Volume 30.

[5] Puspitasari, R., \& Susanto, I. (2011). Analisis Spasial Kasus Demam Berdarah di Sukoharjo Jawa Tengah dengan Menggunakan Indeks Moran. Prosiding Seminar Nasional Matematika dan Pendidikan Matematika dengan tema" Matematika dan Pendidikan Karakter dalam Pembelajaran". Yogyakarta: UNY.

[6] Kosfeld, R., \& Dreger, C. (2006). Thresholds for employment and unemployment: A spatial analysis of German regional labour markets, 1992-2000. Papers in Regional Science, 85(4), 523-542.

[7] Mitchell, A. (2005). The ESRI Guide to GIS Analysis, Volume 2: Statistical Measurements and Statistics.

[8] Kartika, Y. (2007). Pola Penyebaran Spasial Demam Berdarah Dengue di Kota Bogor tahun 2005. Departemen Statistika, Institut Pertanian Bogor.

[9] Perobelli, F., \& Haddad, E. (2003). Brazilian interregional trade (1985-1996): an exploratory spatial data analysis. ANPEC-Associação Nacional dos Centros de Pósgraduação em Economia [Brazilian Association of Graduate Programs in Economics].

[10] Lee, J., \& Wong, D. W. S. W. (2000). GIS and Statistical Analysis with ArcView. John Wiley \& Sons, Inc., New York, USA; 2001.p. 192.

[11] Oyana, T. J., Margai, F. M., Evans, A., Scott, K. E., \& MacRoy, P. (2006, November). Identification of spatial patterns and neighborhood characterization of elevated levels of child lead poisoning in the city of Chicago, 1997-2003. In Race, Ethnicity \& Place Conference. November (pp. 1-4). 